\section{Spatial planning and land-use management tools in aid of securing water sustainability: The case study of Mogalakwena Local Municipality in South Africa}

\author{
Hildegard Rohr, Juaneé Cilliers \& Werner Fourie
}

http://dx.doi.org/10.18820/2415-0495/trp71i1.2

Peer reviewed and revised October 2017

\begin{abstract}
The concept of Water-Sensitive Settlements is gaining importance within broader sustainability thinking. There is limited research in urban planning literature, in particular, on the quantitative impact of land-use decisions on water resources.

This article proposes a spatial modelling approach that combines land-use and water-consumption data in order to identify areas of intervention, which could feed into future development plans and strategies. The research considers the Mogalakwena Local Municipality as a case study, because of its socio-economic characteristics as well as the spatial and billing data that were generated from an ongoing research project funded by the Water Research Commission. It was evident that spatial modelling of land use and water consumption can be utilised as a tool to determine the impact of land-use decision on water resources.

Having generated spatial information on 'where' and by 'which' land use the demand for water is highest, municipal planners are able to make informed future land-use decisions, which will ultimately affect water resources. In addition, the information can be used to enforce new thinking within the municipal spatial planning domain on, among others, implementing water-sensitive mitigation measures such as revisiting water tariff structures; re-evaluating the promised level of services; implementing water-efficiency building regulations, and rethinking the business-as-usual approach to settlement planning.
\end{abstract}

Keywords: Spatial modelling, spatial planning, WSUD, Water-Sensitive Settlements

\section{RUIMTELIKE BEPLANNING EN GRONDGEBRUIKBESTUURSINSTRUMENTE TEN EINDE WATERVOLHOUBAARHEID TE VERSEKER: DIE GEVALLESTUDIE VAN MOGALAKWENA PLAASLIKE MUNISIPALITEIT IN SUID-AFRIKA}

Die belangrikheid van die konsep Water Sensitiewe Nedersettings neem toe binne die raamwerk van breër volhoubaarheidsdenke. Daar is beperkte navorsing, veral in stedelike beplanningsliteratuur, oor die kwantitatiewe impak van grondgebruiksbesluite op water as 'n hulpbron.

Die navorsing in hierdie artikel stel 'n ruimtelike modelleringsbenadering voor wat grondgebruik- en waterverbruikdata kombineer ten einde areas van ingryping te identifiseer en wat ingesluit kan word in toekomstige ontwikkelingsplanne en -strategieë. Die navorsing gebruik die Mogalakwena Plaaslike Munisipaliteit as gevallestudie weens sy sosio-ekonomiese eienskappe, asook die ruimtelike en faktuurdata wat uit 'n deurlopende navorsingsprojek gegenereer is, befonds deur die Waternavorsingskommissie. Daar is oortuigend bewys dat ruimtelike modellering gebruik kan word as hulpmiddel om die impak van grondgebruikbesluite te rig, asook om groei patrone te stimuleer.

Met ruimtelike inligting oor 'waar' en deur 'watter' grondgebruik die vraag na water die hoogste is, kan munisipale beplanners ingeligte toekomstige grondgebruikbesluite neem wat uiteindelik weer sal impakteer op waterhulpbronne. Daarbenewens kan die inligting gebruik word om nuwe denke in die munisipale ruimtelike beplanningsdomein op te stel. Dit sluit ondermeer in die implementering van maatreëls soos die hersiening van waterbetalingstrukture, die herbeoordeling van die beloofde vlak van dienste, die implementering van waterdoeltreffendheidsbouregulasies, en die heroorweging van die tradisionele benadering tot nedersettingsbeplanning.
Sleutelwoorde: Ruimtelike beplanning, ruimtelike modellering, WSUD, Water Sensitiewe Nedersettings

\section{TLHOPHISO YA SEPAKAPAKA LE TSHEBEDISO YA DISEBEDISWA TSA TAOLO YA LEFATSHE BAKENG SA THUSO YA HO FUMANA POLOKO YA METSI: THUTO YA MOHLALA YA MMASEPALA WA SELEHAE WA MOGALAKWENA, AFRIKA BORWA}

Taba ya bodulo bo nang le thokomelo ya metsi (WSS) bo ntse bo fumanwa bo le bohlokwa monahanong wa ho boloka. Diphuputso tse teng di nyenyane bakeng sa kgahlamelo ya dipalopalo hodima diqeto tsa tshebediso ya lefatshe ho disebediswa tsa metsi, haholoholo dingolweng tsa thophiso ya ditoropo.

Atikele ena e hlahisa mokgwa wa popo ya sepakapaka e kopanyang tshebediso ya lefatshe le pokello ya dintlha tsa tshebediso ya metsi ho bontsha dibaka tsa bonamodi, tse ka fepang merero ya ntlafatso le maano a nako e tlang. Diphuputso di sheba Mmasepala wa selehae wa Mogalakwena jwalo ka thuto ya mehlala, ka lebaka la matshwao a moruo wa setjhaba Mmasepaleng; ha mmoho le pokello ya dintlha tsa sepakapaka le ditefello; tse ileng tsa fumanwa ho tswa projekeng ya diphuputso e tswellang pele, e lefelletsweng ke Water Research Committee.

Ho totobetse hore popo ya sepakapaka tshebedisong ya lefatshe le metsi, di ka sebediswa jwalo ka disebediswa bakeng sa ho hlahisa tshusumetso qetong ya tshebediso ya lefatshe hodima disebediswa tsa metsi.

Ka ho hlahisa tlhahisoleseding ya sepakapaka ka hore ke 'kae' le hore 'ke se feng' sebaka seo thoko ya sona ya metsi e leng hodimo ka ho fetisisa, bahlophisi ba Mmasepala ba kgona ho etsa diqeto tse tsebisahalang tsa bokamoso tse amang mehlodi ya lefatshe, tseo qetellong di tla ba le kgahlamelo ho disebediswa tsa metsi. Ho tlatselletsa, thahisoleseding e ka sebediswa ho tiisa monahano o motjha tlhophisong ya sepakapaka sebakeng sa Mmasepala; e kenyelletsang ho fokotsa mekgwa ya tshenyo ya metsi, jwalo ka ho matlafatsa dibopeho tsa ditefiso tsa metsi, tekolobotjha ya boemo boo ho tshepisanweng ka bona ba ho fana ka ditshebeletso, ho phethahatsa melao ya metsi e ahang bokgoni le ho nahana 
botjha mokgwa wa kgwebo-ka-tlwaelo ha ho tluwa thophisong ya bodulo.

Mantswe a sehlooho: Popo ya Sepakapaka, Tlhophiso ya Sepakapaka, WSUD, Bodulo bo nang le TIhokomelo ya Metsi

\section{INTRODUCTION}

Since the $18^{\text {th }}$ century, towns and cities have become dependent on engineered infrastructure designed to supply safer and larger quantities of water to growing urban communities (Goodland, Orlando \& Anhang, 2001: 24; Winiwarter, Haidvogl, Hohensinner, Hauer \& Burkner, 2016: 211), leading to the development of a modern water- and waste water-treatment system, consisting of dams, pipes, treatment plans and storm-water infrastructure (DWS, 2015: 14).

According to Marsalek, JiménezCisneros, Malmquist, Karamouz, Goldenfum \& Chocat (2006: 3), this artificial hydrological cycle has altered the natural rate and functionality of the cycle of replenishment and the hydrological responses of watersheds, making the renewability of water resources increasingly questionable. Urban population growth projections indicate that, between 2000 and 2050, the amount of urban space will need to double in developed countries and expanded by $326 \%$ in developing countries to accommodate the expected growth (Angel, Parent, Civco \& Blei, 2010: 49). According to Grimm, Faeth, Golubiewski, Redman \& Wu (2008: 756-760), urbanisation not only results in changes in land cover, but also in hydrological systems, biogeochemistry, climate, and biodiversity. Seto, Fragkias, Güneralp \& Reilly (2011: 1) have also proven that rapid and unplanned land-cover change driven by urbanisation patterns has a direct qualitative impact on local hydrological and ecological systems. In addition, urbanisation and land-use change also express a quantitative need for water resources, which, in most cases, will result in increased water resource consumption patterns, due to the higher level of services and access to services provided in urban areas (UN Habitat, 2013: 70). The IWMI (2006: 8) reports that rising income levels, sanctioned by urbanization, will also change food habits towards richer and more varied diets "not only to increasing consumption of staples cereals, but also a shift in consumption patterns away from cereal crop towards livestock and fish products and high-value crops" which, in order to produce, require far more water resources.

The United Nations (UN) states that current water use (direct and indirect) is growing at twice the rate of the population (UN Habitat, 2013: 18) and will continue to increase with rising demands from municipal, industrial and agricultural uses (IWMI, 2006: 8). As such, many countries now face economic water scarcity, as illustrated in Figure 1, which depicts the IWMI analysis done for the comprehensive assessment for water management in agriculture using the Watersim model on a global scale (IWMI, 2006: 8).

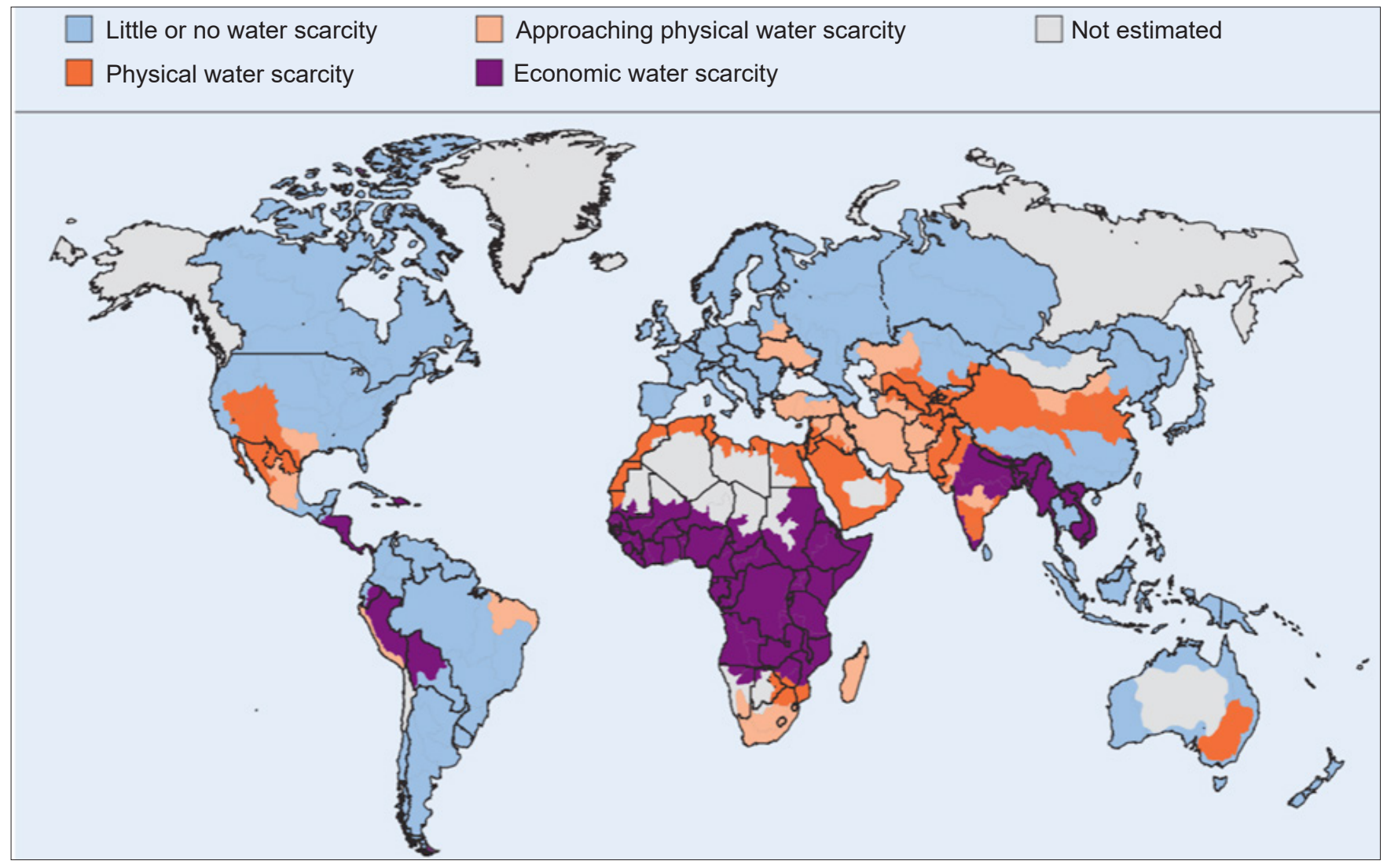

Figure 1: IWMI status of water scarcity on a global scale

Source: UN-Water (2006: 8) 
Figure 1 shows that South Africa has limited water resources and the lack of understanding in terms of the impact of land-use decisions taken by spatial planners has had a detrimental impact on South Africa's already scarce water resources. The enactment of the Spatial Planning and Land-Use Management Act of 2013 now presents opportunities for integrated planning approaches ${ }^{1}$ (RSA, 2013).

One of these approaches is to utilise spatial modelling tools (refer to Table 2) used by spatial planners to determine the impact of land-use decisions and, ultimately, to analyse growth patterns. Both of these have a qualitative and quantitative impact on water resources. The hydrological impacts of land-cover change are well-documented, placing the focus primarily on streamflow, stormflow, surface runoff generated, and groundwater impact. However, limited research can be found on the quantitative impact of land-use decisions on water resources, especially in urban planning literature.

The research emphasises the importance of translating water sensitivity into spatial planning practices. It also provides recommendations for a typical category B municipality, constrained by limited spatial data, on how to identify planning opportunities to facilitate the transition towards creating Water-Sensitive Settlements(WSSs).

\section{STRATEGIC ISSUES AND REALITIES IN SOUTH AFRICA}

\subsection{Lasting impact of spatial decisions}

The early 1990s marked the end of the apartheid era in South Africa and with this, Government introduced the Reconstruction and Development Plan (RDP) which was, and still is, committed to establishing viable communities for housing beneficiaries in areas close to economic opportunities and to health,

Act 16 of 2013 , Section 4(c) educational, and social amenities as well as transport infrastructure (O'Malley, 2016). According to Oosthuizen (2000: 103), this could only be achieved by either "filling up" open space in large cities, or by expanding the cities' borders into adjacent rural areas. The latter resulted in large-scale, low-income housing developments with lowdensity patterns (Boshoff, 2014: 13), consuming significant amounts of land per capita and generating even larger per capita infrastructure costs (UN Habitat, 2013: 29). Although the RDP strategy echoed the integrated planning and sustainable development principles of Agenda 21 (Rowlston \& Schreiner, 2011: 50), the ambitious programme to eradicate the housing backlog hardly considered the fact that it accelerated rapid urban expansion and urban sprawl. According to the latest State of South African Cities Report (SACN, 2016: 165), the "typical South African city is characterised as being resource intensive and suffers from inefficiencies across sectors (energy, food, water, waste, and transport)", of which the water sector lies centrally.

\subsection{Depleting natural ecosystems}

The loss of ecological formations in South Africa is a direct result of the overall population growth, rapid urbanisation and increasing urban sprawl (SACN, 2016: 5). As such, over half of South African rivers are classed as threatened, of which $25 \%$ critically endangered, $19 \%$ endangered, and $13 \%$ vulnerable (Driver, Sink, Nel, Holness, Van Niekerk, Daniels, Jonas, Majiedt, Harris \& Maze, 2012: 6). Wetlands only make up $2.4 \%$ of South Africa's land surface area; yet the 2011 National Biodiversity Assessment revealed that $48 \%$ of the country's wetlands types are critically endangered, followed by $39 \%$ of estuaries types (Driver et al., 2012: 7). While South Africa has a plethora of environmental legislation and instruments promoting ecologically sustainable development through systematic biodiversity planning (Nel, Driver, Strydom, Maherry, Petersen, Hill,
Roux, Nienaber, Van Deventer, Swartz \& Smith-Adao, 2011: 7), the above figures reveal a different reality. Furthermore, the country is expected to face a water demandsupply gap of nearly $17 \%$ by 2030 (2030 Water Resource Group, 2009: 63). The DWS (2014: 7) warns that increases in the water supply cannot match the expected increase in demand without additional and far-reaching interventions. According to the Minister of the Department of Water and Sanitation (DWS), the water crisis cannot be solved through engineering alone; demand management regarding both efficiency and allocation will have to play a large part in the efforts to close the water demand-supply gap in South Africa (DWS, 2014: 11).

\subsection{Water-resource infrastructure: Water losses and non-revenue water}

Water-resource planning, dealing with balancing the water demand and supply, relies on water-reconciliation studies and water-metering information to determine how much water is being used and wasted (DWA, 2013b: 18-20; DEA, 2013: 55-58). The International Water Association water balance has been modified for South Africa's situation to include (DWS, 2015: 45-46):

- Revenue water regarding (i) billed metered consumption and (ii) billed un-metered consumption (e.g., flat rate tariff and free basic water used though unbilled unmetered standpipe or yard connections), and

- Non-revenue water in terms of (i) unbilled metered (e.g., government buildings or parks); (ii) unbilled unmetered (e.g., estimated water used for legitimate purposes such as firefighting and also usage above the free basic water limit for unmetered, unbilled standpipe and yard connections usage); (iii) apparent losses (e.g., water used through illegal connections, water used but not billed for because of inaccurate meters, data transfer errors, low-estimate readings or any administrative errors, and (iv) real losses which refer to water 
that leaks from the system through pipes and connections, or overflows from reservoirs.

According to the DWS (2015: 45), $39 \%$ of all municipal water is considered non-revenue water, and $36 \%$ is classified as water losses, as reflected in South Africa's Infrastructure Leakage Index of 5.3. The highest percentage of water losses and usage of non-revenue water occurs in the smaller, more rural municipalities, which only demand approximately $17 \%$ of the total municipal system input, compared to metropolitan municipalities demanding over $50 \%$ of the total national volume (DWS, 2015: 45). However, concluding remarks from ten water-reconciliation strategies and the "905 all town studies" (DWA, 2013b: 23) indicate that water-services authorities have limited information to substantiate these figures, due to a lack of billing information (DWA, 2013b: 24).

\section{ADAPTING PLANNING APPROACHES}

For many South Africans, water scarcity is an abstract concept, as they believe that water simply runs from a tap. For others, it is a stark reality when rivers, streams and perhaps the one communal tap runs dry, causing major food shortages, with many going hungry for days at a time. Although access to basic services such as water is a constitutional right, the provision of sustainable water supply to
55.6 million citizens (Statistics South Africa, 2016: 19) in a semiarid country is an overwhelming task, as the current and expected future demand exceeds the available supply.

\subsection{Strategic water-resource planning goals}

Like many other countries, South Africa is committed to sustainable development, as evident in the Rio Declaration on Environment and Development, the World Summit on Sustainable Development, the World Summit for Social Development, the Programme of Action of the International Conference on Population and Development, the Beijing Platform for Action, the United Nations Conference on Sustainable Development, and the most recent 2030 Agenda for Sustainable Development. The latter, which came into effect on 1 January 2016, stipulates 17 Sustainable Development Goals (SDG) with 169 targets to address specific issues (UN, 2015: 10).

The 2030 SDG calls attention to sustainable development, which recognises that eradicating poverty in all its forms and dimensions, combating inequality within and among countries, preserving the planet, creating sustained, inclusive and sustainable economic growth and fostering social inclusion are linked to each other and are interdependent (UN, 2015: 5).

Table 1: Water planning-related goals derived from the SDG

\begin{tabular}{|c|c|c|}
\hline $\begin{array}{l}\text { SDG } \\
\text { goals }\end{array}$ & $\begin{array}{c}\text { Goal } 6 \\
\text { "Clean water and sanitation" }\end{array}$ & $\begin{array}{c}\text { Goal } 11 \\
\text { "Sustainable cities and communities" }\end{array}$ \\
\hline Aim & $\begin{array}{l}\text { Availability and sustainable management of } \\
\text { water and sanitation. Refers to: } \\
6.1 \text { : safe and affordable drinking water } \\
\text { 6.2: adequate and equitable sanitation } \\
6.3 \text { : safe water reuse } \\
\text { 6.4: water scarcity and water use efficiency } \\
6.5 \text { integrated water-resource management }\end{array}$ & $\begin{array}{l}\text { Make cities and human settlements inclusive, } \\
\text { safe, resilient and sustainable. Refers to } \\
\text { 11.1: basic services } \\
\text { 11.3: integrated and sustainable human } \\
\text { settlement planning } \\
\text { 11.5: water-related disasters } \\
\text { 11.6: per capita environmental impact of cities } \\
\text { 11.7: green public spaces }\end{array}$ \\
\hline Focus & $\begin{array}{l}\text { By } 2030 \text {, expand international } \\
\text { cooperation and capacity to developing } \\
\text { countries in water-related activities and } \\
\text { programmes } \\
\text { Support and strengthen the participation } \\
\text { of local communities in improving water } \\
\text { and sanitation management }\end{array}$ & $\begin{array}{l}\text { - } \\
\text { - } \quad \text { Support positive economic, social, and } \\
\text { environmental links } \\
\text { By 2020, substantially increase } \\
\text { inclusion, resource efficiency, mitigation } \\
\text { and adaptation to climate change, } \\
\text { resilience to disasters } \\
\text { - Support least developed countries } \\
\text { in building sustainable and resilient } \\
\text { buildings }\end{array}$ \\
\hline
\end{tabular}

Source: UN (2015: 22-26)

Two goals are directly related to strategic water-resource planning and management, and human settlements (see Table 1).

\subsection{From goals to practice through Water-Sensitive Urban Design}

Within these SDGs, the notion of WSUD is accentuated as a tool for advancing the principles of sustainable development through a multi-disciplined approach to urban water management, which aims to holistically consider the environmental, social and economic consequences of water management and infrastructure (Wong, 2006). WSUD has evolved from its early association with storm-water management that focused primarily on sustainable urban water drainage systems (SuDS), into an approach that integrates the urban water cycle (including potable water, waste water and storm-water) and the built and natural urban landscape to provide multiple benefits to society. The concept of WSUD was introduced in the conceptual framework of the "Water-Sensitive City" (Wong \& Brown, 2008; Brown, Keath \& Wong, 2008). Such a city serves as a potential water supply catchment, providing a range of different water sources at a range of different scales, and for a range of different uses; provides ecosystem services and a healthy natural environment, thereby offering a range of social, ecological, and economic benefits; and consist[s] of water sensitive communities where citizens have the knowledge and desire to make wise choices about water, is actively engaged in decision-making and demonstrate[s] positive behaviours such as conserving water at home (Wong, Allen, Brown, Deletić, Gangadharan, Gernjak, Jakob, Johnstone, Reeder, Tapper \& Vietz 2013: 7).

WSUD was proposed as a tool, within a broader urban and rural landscape, to realise the objectives of a WSC.

Currently, the concept of the WSC is progressively being refined to adapt to local situations and realities. South Africa's framework for WSUD suggests that a WSS is one where the management of the water cycle 


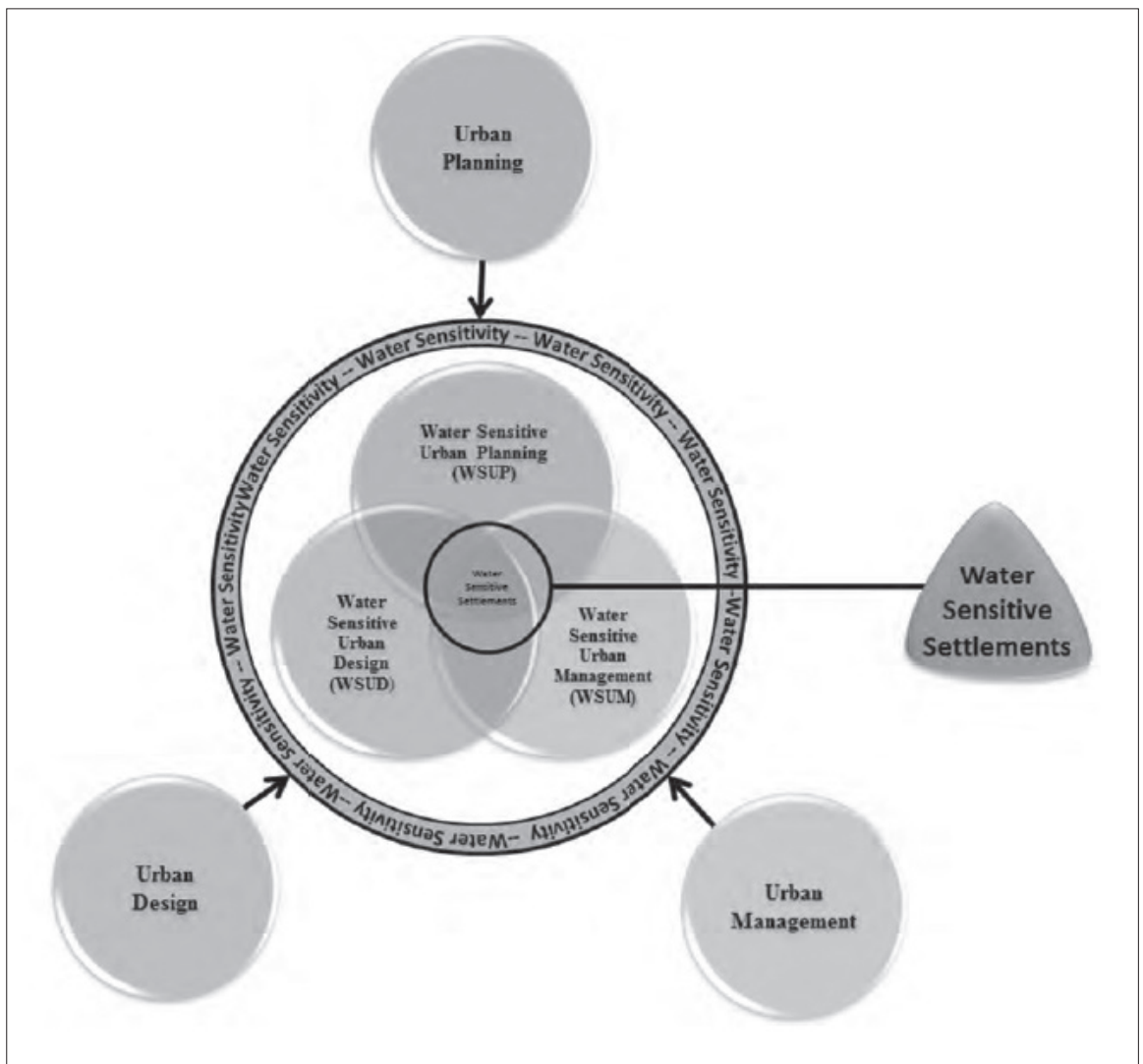

Figure 2: The integration of WSUD, WSUP, and WSUM towards WSS Source: Armitage et al. (2014: 19)

is undertaken in a water-sensitive manner with the overall objective of ecologically sustainable development (Armitage, Fisher-Jeffes, Carden, Winter, Naidoo, Spiegel, Mauck \& Coulsen, 2014: 8). The framework highlights that WSS consists of three components, but that it should be considered in an integrated manner, which includes (Armitage et al., 2014: 19): (i) Water-Sensitive Urban Design (WSUD); (ii) Water-Sensitive Urban Planning (WSUP) which brings together two components 'water sensitivity' and 'urban planning', ensuring that 'urban planning' is undertaken in a manner that considers and treats water sensitively, and (iii) Water-Sensitive Urban Management (WSUM), as illustrated in Figure 2.

While WSUD is considered to be a well-researched and well-practised concept regarding technical illustrations and approaches to the urban water infrastructure component, information is limited as to exactly how design and planning should engage with the concept of WSS, specifically in the South African context. Concluding remarks from the framework state that municipal authorities need to go beyond the delivery of basic services to ensure urban resilience by reconfiguring cities through strategic planning and investment in order to address future uncertainties such as resource shortages (Armitage et al., 2014: 35). Municipalities with limited funding and capacity must "do what you can with what you have", beginning with strengthening local legislation and regulations to encourage this transition (Armitage et al., 2014: 28).

\section{THE ROLE OF SPATIAL PLANNING TO GUIDE WSUD}

The dependency and close relationship between human and natural systems imply that cities and settlements cannot be sustainable or resilient until their reliance on ecosystem services is recognised (Cilliers \& Cilliers, 2016: 15) and the value of ecologically sustainable development acknowledged (Armitage et al., 2014: 46). Despite this close association, a silo-planning approach is currently impeding the successful integration of spatial planning and environmental resource management, enforced by institutional arrangements, often to the detriment of sustainable development.

The recently enacted Spatial Planning and Land-Use Management Act 16 of 2013 (SPLUMA) firmly mandates municipal planning as primarily the task of local governments and declares that "sustainable development of land requires the integration of social, economic and environmental considerations in both forwardplanning and ongoing land use management to ensure that development of land serves present and future generations" (RSA, 2013: 4). SPLUMA (Act 16 of 2013) also states that the RSA's spatial planning system consists of, among others, (i) a land-use scheme that seeks to manage the legality of existing land uses and buildings, and (ii) a spatial development framework intended to plan for future development of a municipality. Within the scope of SPLUMA, new opportunities arise where spatial planning could guide future WSUD approaches, as explained accordingly.

\subsection{Planning for existing land uses}

SPLUMA (Act 16 of 2013) stipulates that municipalities should now develop a wall-to-wall Land-Use Scheme, implying the inclusion of all areas (including traditional villages and rural areas). Section 26(1)(a) of the Act states that "an approved land use scheme has the force of law, and all landowners and users of land, including a municipality, a state-owned enterprise, and organs of state within the municipal boundary, are bound by the provision of such land use scheme" (RSA, 2013:x36). Section 26(2)(a) further states that "land may only be used for the purposes permitted by a land use scheme" (RSA, 2013: 36). As such, spatial planners have the opportunity to develop and enforce water-conscious land-use planning, 
which can facilitate WSS. However, the compilation of a wall-to-wall land-use scheme is a challenging task, in particular with the vast majority of rural land uses being un-surveyed. In this regard, spatial planning should thus seek integration between different planning sectors in an attempt to build a data basis for land-use planning. In this sense, a land-use scheme should consider the protection and management of ecological formations, to inform the development of WSS. The Atlas of Freshwater Ecosystems Priority Areas (FEPA) in South Africa (Nel et al., 2011: 7) might offer insights, as it enforces systematic biodiversity planning by identifying areas important for biodiversity conservation (Nel et al., 2011: 7).

Figure 3(A-C) illustrates how different spatial data sets from two sectors can be overlapped and integrated to guide land-use and water-resource planning and management.
Figure 3(A) illustrates the FEPA identified within the Limpopo Water Management Area. It also shows a zoomed in image of a wetland cluster that allows for important ecological processes, as identified by $\mathrm{Nel}$ et al. (2011:14). Figure 3(B) illustrates the overlap when incorporating land-use data, originally not included in the National Freshwater Ecosystem Priority Areas, thus now generating a wall-to-wall land audit, where human impact on water resources becomes evident. Figure 3(C) illustrates the 5-year spatial growth pattern of the rural settlement footprint, in relation to the water resources.

\subsection{Planning for future growth}

Translating existing land-uses into future demand requires the inputs of spatial modelling systems. According to Abebe (2011: 32) and Armitage et al. (2014: 113-127), some models and techniques are designed to simulate future urban growth. Table 2 enumerates a selection of local landuse change models currently utilised by various departments and cities in South Africa.

The bulk of land-use models employed in South Africa is GISbased or linked to spreadsheets that contain demographic or housing projections (Wray et al., 2013: 23). The most advanced modelling system currently used in some of South Africa's metropolitan areas such as eThekwini, Nelson Mandela Bay and Johannesburg is the CSIR UrbanSim model (CSIR, 2011: 18).

However, the UrbanSim model is considered to be highly technical, data-intensive and very expensive (Wray et al., 2013: 55), hence the reason why it is only used by metropolitan municipalities. The inclusion of urban water as part of these modelling systems was not evident, and such possibilities should be explored.

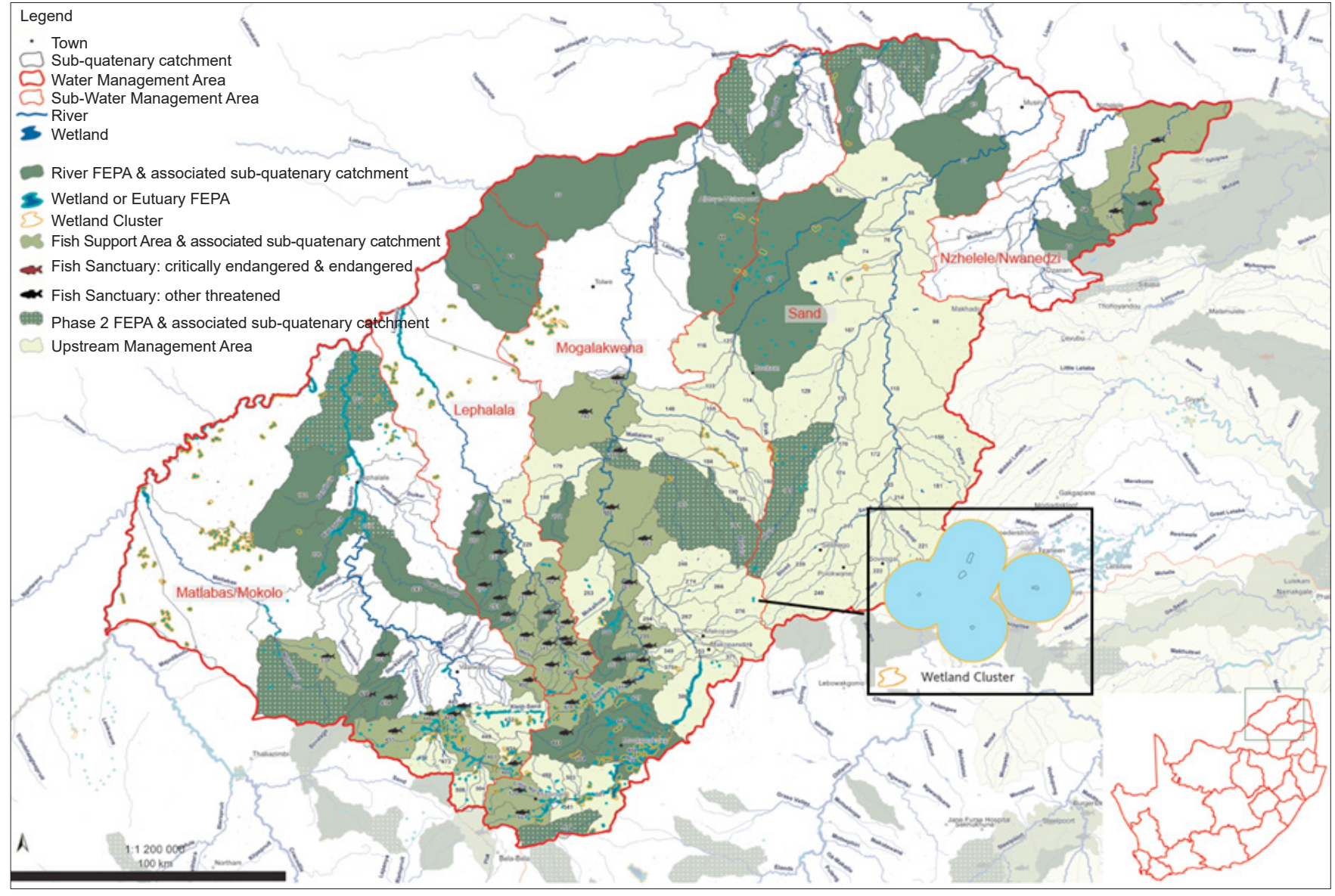

Figure 3(A):Freshwater ecosystems priority areas within the Limpopo Water Management area

Source: $\quad$ Nel et al. (2011: 15) 


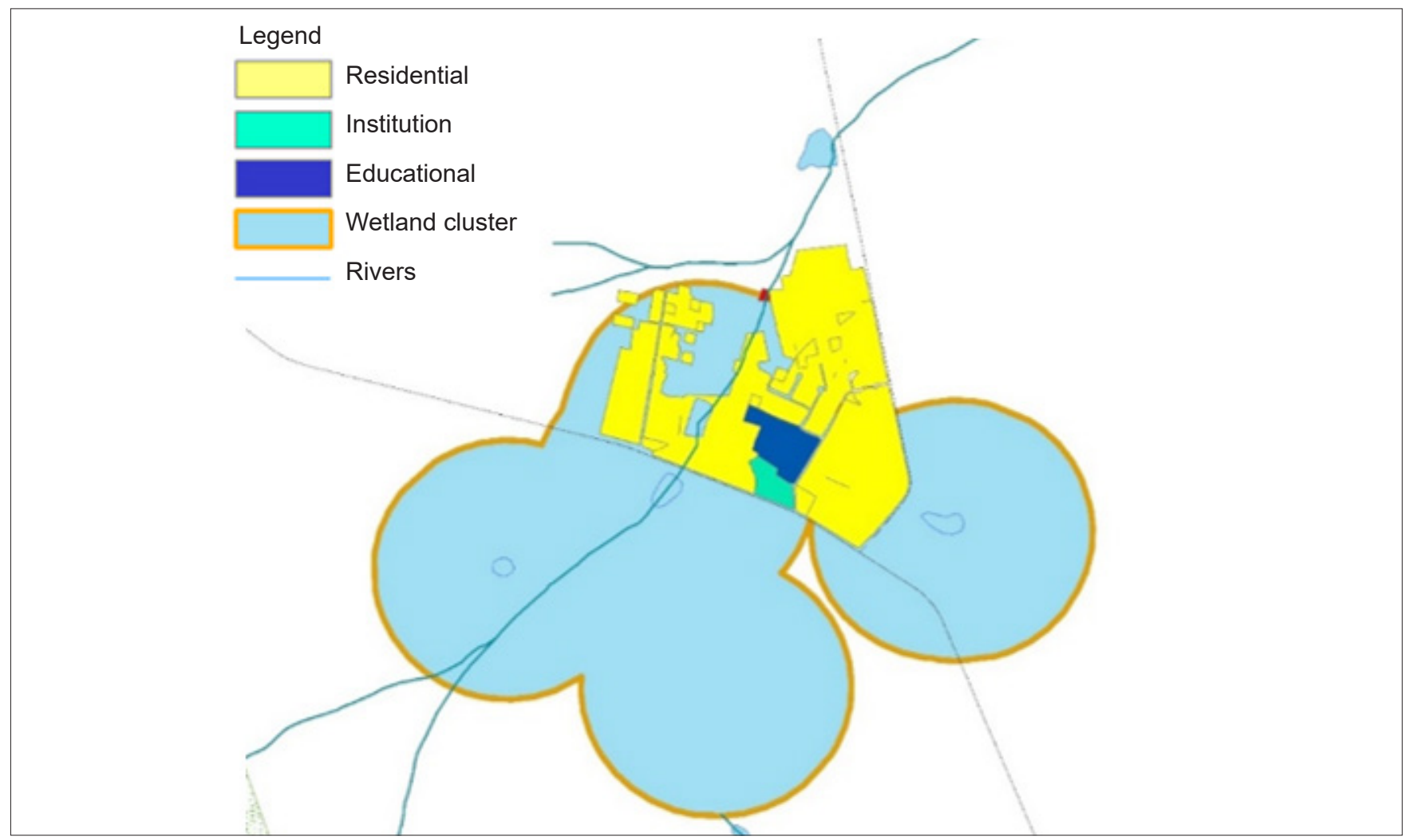

Figure 3(B):Rural land-use survey data in 2010. Spatial representation of the wetlands cluster and land-audit data to guide a wall-to-wall land-use scheme, as required by Section 26 of SPLUMA

Source: $\quad$ Authors' own compilation, adapted from Nel et al., 2011: 15

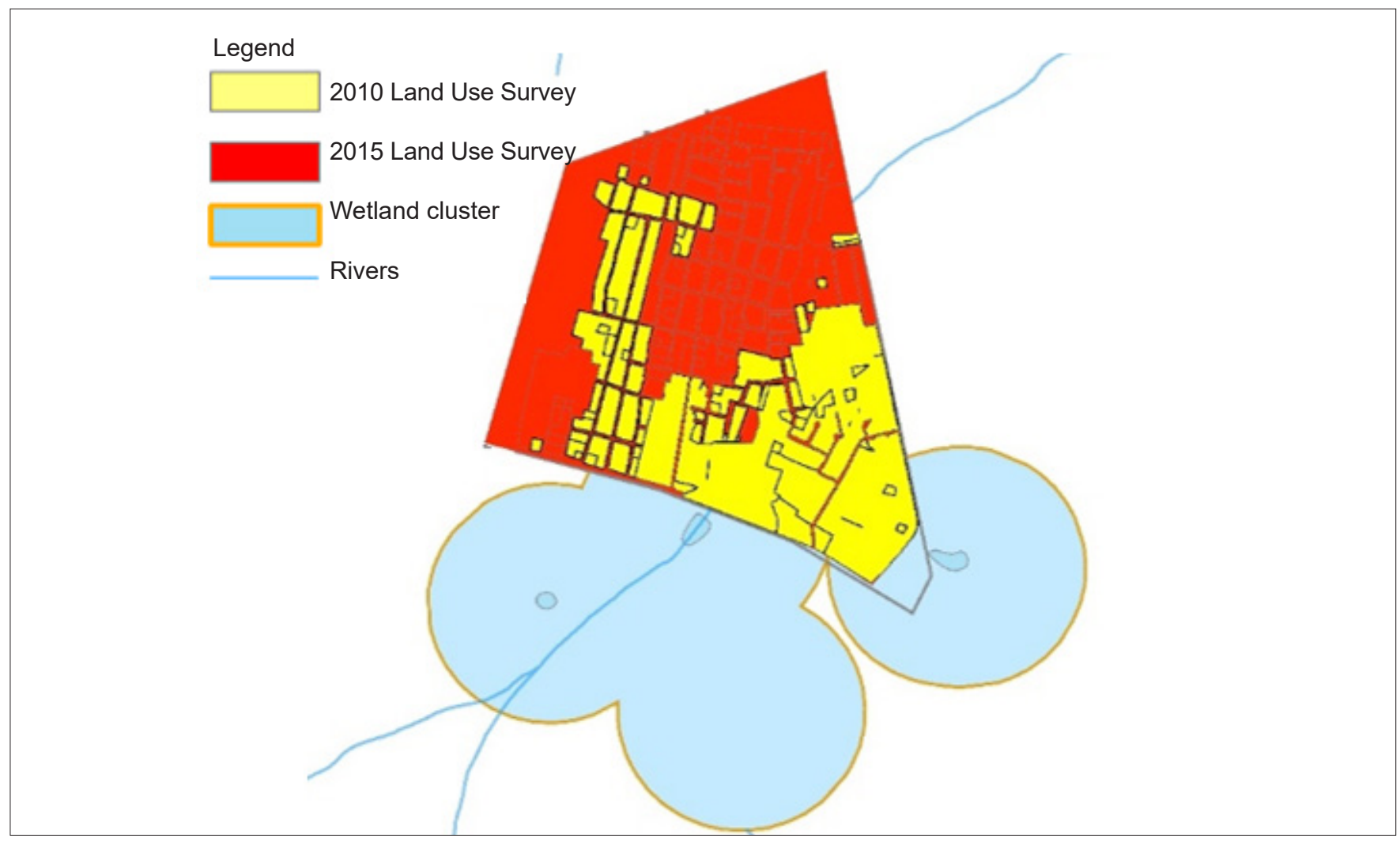

Figure 3(C): Rural land-use survey data of 2016. Spatial representation of expanding rural footprint within five years and the growing impact on the wetlands cluster

Source: $\quad$ Authors' own compilation, adapted from Nel et al., 2011: 15 
Table 2: $\quad$ Selected South African land-use change modelling initiatives

\begin{tabular}{|c|c|c|}
\hline Model & Model type & Main purpose and key model components \\
\hline $\begin{array}{l}\text { Gauteng Integrated } \\
\text { Transport Modelling }\end{array}$ & $\begin{array}{l}\text { Econometric/ } \\
\text { microsimulation/ ABM }\end{array}$ & $\begin{array}{l}\text { GITMC builds on the data and modelling created in the CSIR UrbanSim and MATSim simulation project } \\
\text { to produce urban growth scenarios based on different infrastructure initiatives. }\end{array}$ \\
\hline $\begin{array}{l}\text { Gauteng Infrastructure } \\
\text { Planning Tool }\end{array}$ & GIS-based model & $\begin{array}{l}\text { Developed to assist with the short- and medium-term integrated planning of education and health } \\
\text { facilities within the province. Using the current location of schools, hospitals and clinics, the future } \\
\text { demand and location of new facilities are modelled, providing planners with a tool to test different } \\
\text { development scenarios for determining optimal locations of public social facilities. }\end{array}$ \\
\hline $\begin{array}{l}\text { Gauteng Department of } \\
\text { Economic Development }\end{array}$ & GIS-based models & $\begin{array}{l}\text { The model analyses the existing urban patterns for Gauteng and serves as a basis for future spatial } \\
\text { strategies that feed into supporting policy and planning decisions. The models include an urban profile, } \\
\text { urban morphology, connectivity, bid rent, and virtual model room. }\end{array}$ \\
\hline Cost surface model & GIS-based & Models the costs of providing bulk infrastructure in various locations based on the geotechnical analysis. \\
\hline $\begin{array}{l}\text { e-Thekwini Accessibility } \\
\text { model }\end{array}$ & GIS-based & $\begin{array}{l}\text { The Accessibility model analyses the distances and time required to access certain destinations } \\
\text { spatially. This model typically relates to accessibility analysis of social services and feeds into future } \\
\text { infrastructure investment if the need for such investment is required. }\end{array}$ \\
\hline $\begin{array}{l}\text { City of Cape Town: Urban } \\
\text { Growth Modelling }\end{array}$ & GIS-based & $\begin{array}{l}\text { Models future growth directions by estimating residential, industrial and mixed-use land requirements, } \\
\text { spatially and over time. It also estimates the city services' investment needs. }\end{array}$ \\
\hline CSIR UrbanSim & $\begin{array}{l}\text { Econometric/ } \\
\text { microsimulation/ ABM }\end{array}$ & $\begin{array}{l}\text { CSIR UrbanSim simulates urban growth } 30 \text { years into the future based on current spatial policy and } \\
\text { investment decisions. UrbanSim creates a scenario based on households and businesses about } \\
\text { property and services, developers as suppliers of services, and government provision of infrastructure } \\
\text { and services. }\end{array}$ \\
\hline $\begin{array}{l}\text { UCT School of Architecture, } \\
\text { Planning and Geomatics }\end{array}$ & ABM & Patterns and trends in land occupation change over time in a Cape Town informal settlement. \\
\hline
\end{tabular}

Source: $\quad$ Authors' own compilation, adapted from Gauteng Department of Economic Development, 2011: 74-123; CSIR, 2011: 18-19; Shoko \& Smit, 2013: 60-66; Wray, Musango \& Damon, 2013: 74-78

This is especially important regarding section 21(h) of SPLUMA, requiring the Spatial Development Framework to further identify, quantify and provide location requirements of engineering infrastructure and services provision for existing and future development needs (RSA, 2013: 33).

The growth and resource demand modelling simulations and projections should feed into Spatial Development Frameworks to guide future developments in a municipality. The following case study provides an example of how spatial data and municipal water-billing data can be modelled to estimate the future demand for resources. In this specific case study, the authors argue that water-demand management and conservation should be the first priority in becoming a WCS. In other cities or settlements, the hierarchy of priorities could possibly differ, depending on local context. For example, many cities could be affected by flooding or lack of storage of water resources. As such, these cities' or settlements' first priority would be to use WSUD for flood mitigation or use rainwater-harvesting methods to store excess water.

\section{CASE STUDY: COMBINING SPATIAL AND WATER DATA}

In an attempt to illustrate how spatial modelling could translate to municipalities' 5-year, 10-year and 20-year spatial vision (as required by SPLUMA), the case study of Mogalakwena Local Municipality is presented accordingly. The findings raised in this case study emanated from an ongoing research project funded by the South African Water Research Commission (WRC) titled "Securing Water Sustainability through Innovative Spatial Planning and Land Use Management Tools".

\subsection{Study area}

Mogalakwena Local Municipality is considered to be a typical Category B Local Municipality, located within the iconic Waterberg District Municipality. Mogalakwena functions largely as the interface between the Waterberg District Municipality and the Capricorn District, and is surrounded by mainly deep rural areas of Lephalale Local Municipality to the north and west (Mogalakwena Local Municipality, 2016: 7).

Mogalakwena Local Municipality has a well-defined urban and rural development footprint which consists of 3 proclaimed townships and 178 villages (Mogalakwena Local Municipality, 2016: 8). However, this footprint has already caused severe damage to environmentally sensitive areas (Mogalakwena Local Municipality, 2016: 17). The Municipality's economy is, to a large extent, dependent on agricultural and mining activities; these landuse activities have been criticised for being culprits in surface- and groundwater contamination (Mogalakwena Local Municipality, 2016: 12).

The Mogalakwena Local Municipality 2016/2017 Integrated Development Plan (IDP) identified this as a strategic issue as over $19 \%$ of the municipal area is supplied with underground water resources (Mogalakwena Local Municipality, 2016: 15). According to the water reconciliation strategy conducted for the Olifants River water management area, demand for water is mainly driven by increased mining and associated urban growth (DWA, 2013a: 22). The additional water demand required by 2035 is estimated at 156 million $\mathrm{m}^{3} / \mathrm{a}$. Therefore, far-reaching interventions, in this case through spatial planning and land-use management, must be introduced to meet such demand.

\subsection{Making a case for land use- related water consumption}

Different land uses consume water at different rates. Table 3 illustrates an extract from the billing 


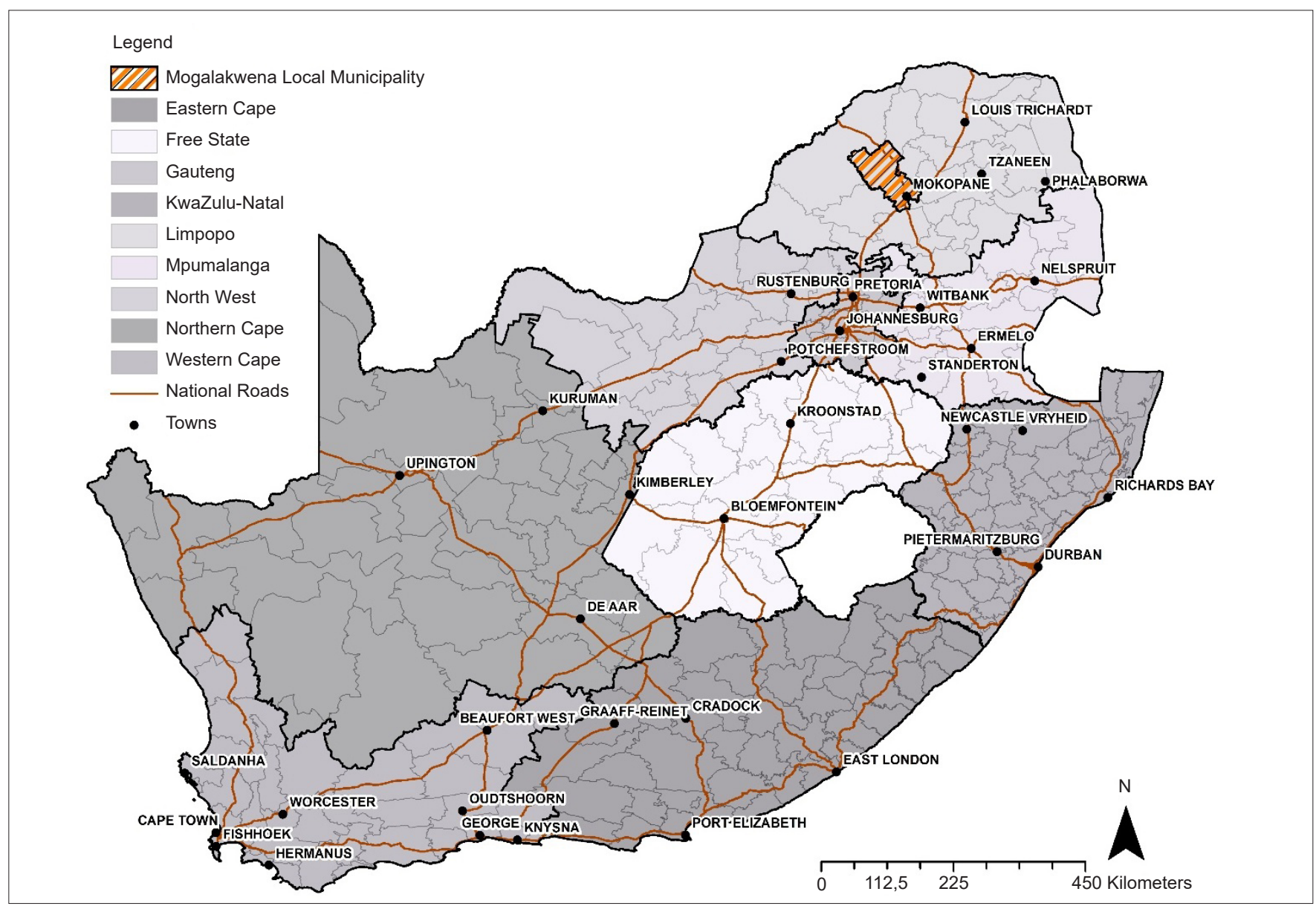

Figure 4: Locational map of Mogalakwena Local Municipality

Source: Authors' own compilation

system of Mogalakwena Local Municipality, obtained from the Field MeterReading, which among other, provides valuable information regarding water consumption in the municipality.

The "Unit" field contains codes of locational information (town, extension, stand number, and subdivision), which can be used to locate the information spatially. The field "YYMM" provides information on the year and month of the reading and "Meter type" indicates that the meter is a water meter (MW08). As all municipalities are required to have a land-use scheme that assigns a land-use right to a specific property, it is possible to overlap different data sets, using the specific property as the common denominator. The land-use and water-consumption data were modelled accordingly to illustrate the results of such spatially. The different land uses were coded in terms of different colours and the average monthly water consumption
Table 3: Extract of the billing system of the Mogalakwena Local Municipality

\begin{tabular}{|c|c|c|c|c|c|c|c|}
\hline Unit & Account & YYMM & Read date & $\begin{array}{c}\text { Meter } \\
\text { reading }\end{array}$ & $\begin{array}{c}\text { Read } \\
\text { type }\end{array}$ & $\begin{array}{c}\text { Meter } \\
\text { ref. }\end{array}$ & $\begin{array}{c}\text { Meter } \\
\text { type }\end{array}$ \\
\hline 100000000000010000000000000 & 1031054 & 200801 & 20080107 & 1840.000 & 3 & 380147 & MW08 \\
\hline 100000000000010000000000000 & 1031054 & 200712 & 20071203 & 1839.000 & 3 & 380147 & MW08 \\
\hline 100000000000010000000000000 & 1031054 & 200711 & 20071101 & 1839.000 & 3 & 380147 & MW08 \\
\hline 100000000000010000000000000 & 1031054 & 200710 & 20071008 & 1837.000 & 3 & 380147 & MW08 \\
\hline 100000000000010000000000000 & 1031054 & 200709 & 20070903 & 1833.000 & 3 & 380147 & MW08 \\
\hline 100000000000010000000000000 & 1031054 & 200708 & 20070801 & 1826.000 & 3 & 380147 & MW08 \\
\hline 100000000000010000000000000 & 1031054 & 200707 & 20070702 & 1814.000 & 3 & 380147 & MW08 \\
\hline 100000000000010000000000000 & 1031054 & 200706 & 20070601 & 1805.000 & 3 & 380147 & MW08 \\
\hline 100000000000010000000000000 & 1031054 & 200705 & 20070502 & 1800.000 & 3 & 380147 & MW08 \\
\hline 100000000000010000000000000 & 1031054 & 200704 & 20070402 & 1798.000 & 3 & 380147 & MW08 \\
\hline 100000000000010000000000000 & 1031054 & 200703 & 20070301 & 1798.000 & 3 & 380147 & MW08 \\
\hline 100000000000010000000000000 & 1031054 & 200702 & 20070205 & 1797.000 & 3 & 380147 & MW08 \\
\hline 100000000000010000000000000 & 1031054 & 200701 & 20070103 & 1796.000 & 3 & 380147 & MW08 \\
\hline 100000000000010000000000000 & 1031054 & 200612 & 20061204 & 1795.000 & 3 & 380147 & MW08 \\
\hline 100000000000010000000000000 & 1031054 & 200611 & 20061101 & 1793.000 & 3 & 380147 & MW08 \\
\hline 100000000000010000000000000 & 1031054 & 200610 & 20061003 & 1791.000 & 3 & 380147 & MW08 \\
\hline
\end{tabular}


of the specific property (relating to specific land-use) is illustrated in terms of height in Figure 4.

Figure 5 indicates that the bulk of water consumption of the Mogalakwena Local Municipality is consumed in the central business district (CBD), followed by the industrial node. Figure 5 further indicates that residential properties in close proximity to the CBD consumed more water than those in outlying areas, which also related to different income levels in these areas.
The spatial modelling of monthly water-consumption data also enables the comparison of land-use and water-consumption data. Table 4 is a summary of the water-billing systems and land-use scheme and illustrates metered consumption (not the total consumption of the Municipality).

Table 4 indicates that land-uses utilised for business in Mogalakwena Local Municipality (of which there are only 315$)$ use nearly twice the total amount of water than residential land uses (of which there are over 30608 ).

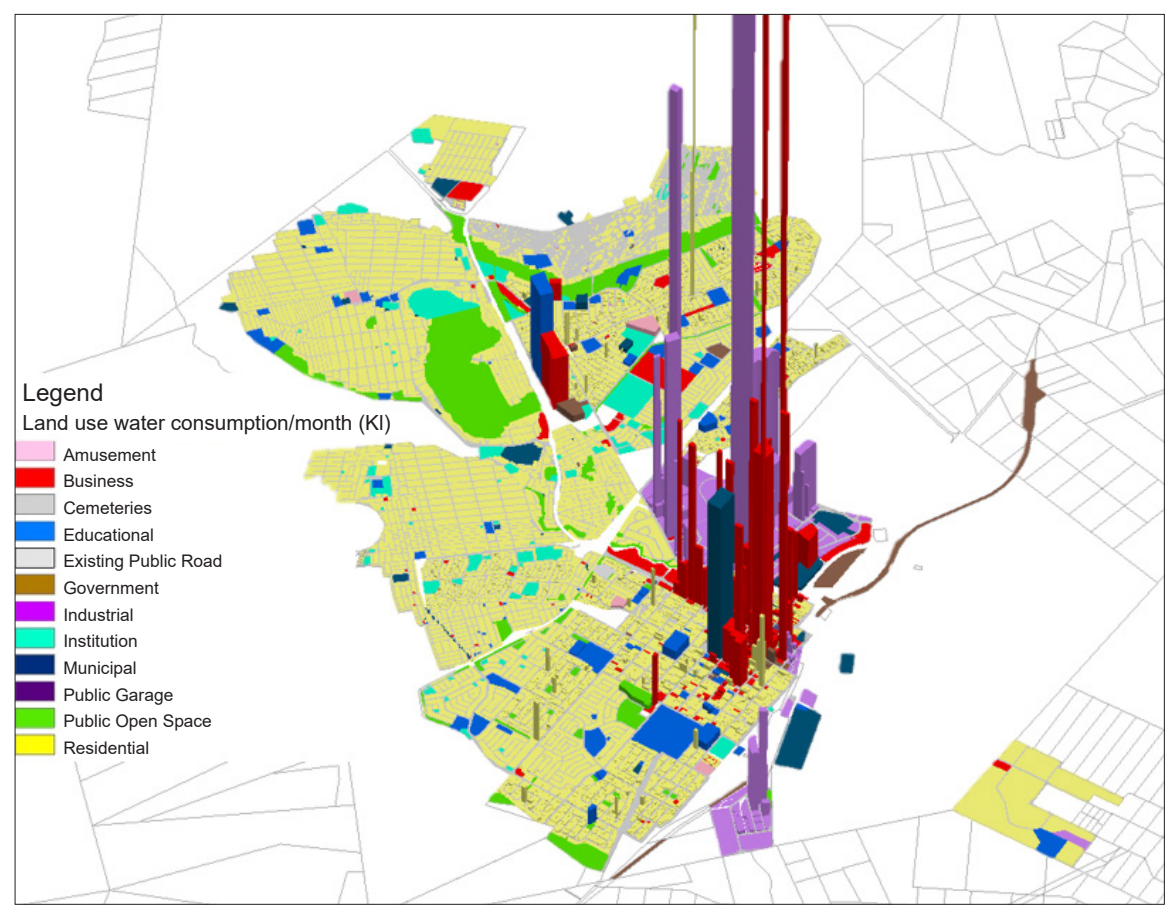

Figure 5: Spatial depiction of water consumption by different land uses in the urban areas of Mokopane town in Mogalakwena Local Municipality

Source: Authors' own compilation

Table 4: Comparison of land-use and water-consumption data in Mogalakwena Local Municipality

\begin{tabular}{|l|c|c|c|}
\hline \multicolumn{1}{|c|}{ Land use } & $\begin{array}{c}\text { Total monthly } \\
\text { consumption (kl) }\end{array}$ & Number of properties & $\begin{array}{c}\text { Average monthly } \\
\text { consumption (kl) }\end{array}$ \\
\hline Amusement & 611 & 7 & 87 \\
\hline Business & 678276 & 251 & 1932 \\
\hline Cemeteries & 0 & 111 & 123 \\
\hline Educational & 13704 & 34 & 70 \\
\hline Government & 2365 & 115 & 0 \\
\hline Existing public road & 0 & 487 & 767 \\
\hline Industrial & 373749 & 120 & 1 \\
\hline Institution & 164 & 77 & 202 \\
\hline Municipal & 15572 & 3 & 37 \\
\hline Public garage & 111 & 120 & 4 \\
\hline Public open space & 469 & 30608 & 12 \\
\hline Residential & 373510 & 33262 & 44 \\
\hline Grand total & 1458597 & & \\
\hline
\end{tabular}

Industrial land uses also consume high amounts of water, as evident in the case study. This information can be used by the Municipality to identify and target land uses with high water consumption. Land uses or even buildings with high water consumption offer greater opportunity to reuse water (the rule of thumb is that up to $90 \%$ of consumed water can be reused) for non-potable purposes such as irrigation or toilet flushing. In this specific case study, businesses, in general, should be targeted to reuse water, as they use nearly twice the amount of residential land uses. Water-sensitive practices such as water reuse, rain and storm-water harvesting can be implemented through building regulations (e.g., SANS 204: Energy Efficiency in buildings regulations requires that $50 \%$ of all hot water in new houses needs to be produced by methods other than electrical element heating - similar regulations could be implemented for water reuse) and land-use controls (e.g., all building should consider either rainwater and storm water harvesting to substitute non-potable water resource demand), both of which can be legally enforced through municipal by-laws.

The spatial modelling for the Mogalakwena Local Municipality also provides valuable information to guide future planning and WSSs. It spatially identifies where, and by which land-use, most of the water is consumed and can be used to predict future growth and demand. The household growth projection was calculated using an Excel-based regression analysis. Households in the Mogalakwena Local Municipality are expected to grow by 4500 additional households in 5 years and 9299 households in 10 years. Based on the spatial modelling data, this translates into an additional monthly demand for water as captured in Table 5.

Table 5 quantifies that, by 2026, an estimated additional $111593 \mathrm{kl}$ of water resources will be required by future households if no mitigation measures are implemented.

Section 21(h) of Act 16 no. 2013 (RSA, 2013: 26) mandates that a Spatial Development Framework 
Table 5: Household growth and water-demand prediction for the Mogalakwena Local Municipality

\begin{tabular}{|c|c|c|c|}
\hline Year & Households & Additional households & Additional water required (KI) \\
\hline 2017 & 84490 & 886 & 10637 \\
\hline 2018 & 85386 & 1782 & 21387 \\
\hline 2019 & 86292 & 2688 & 32251 \\
\hline 2020 & 87206 & 3602 & 43230 \\
\hline 2021 & 88131 & 4527 & 54325 \\
\hline 2022 & 89066 & 5462 & 65539 \\
\hline 2023 & 90010 & 6406 & 76871 \\
\hline 2024 & 90964 & 7360 & 88323 \\
\hline 2025 & 91929 & 8325 & 99896 \\
\hline 2026 & 92903 & 9299 & 111593 \\
\hline
\end{tabular}

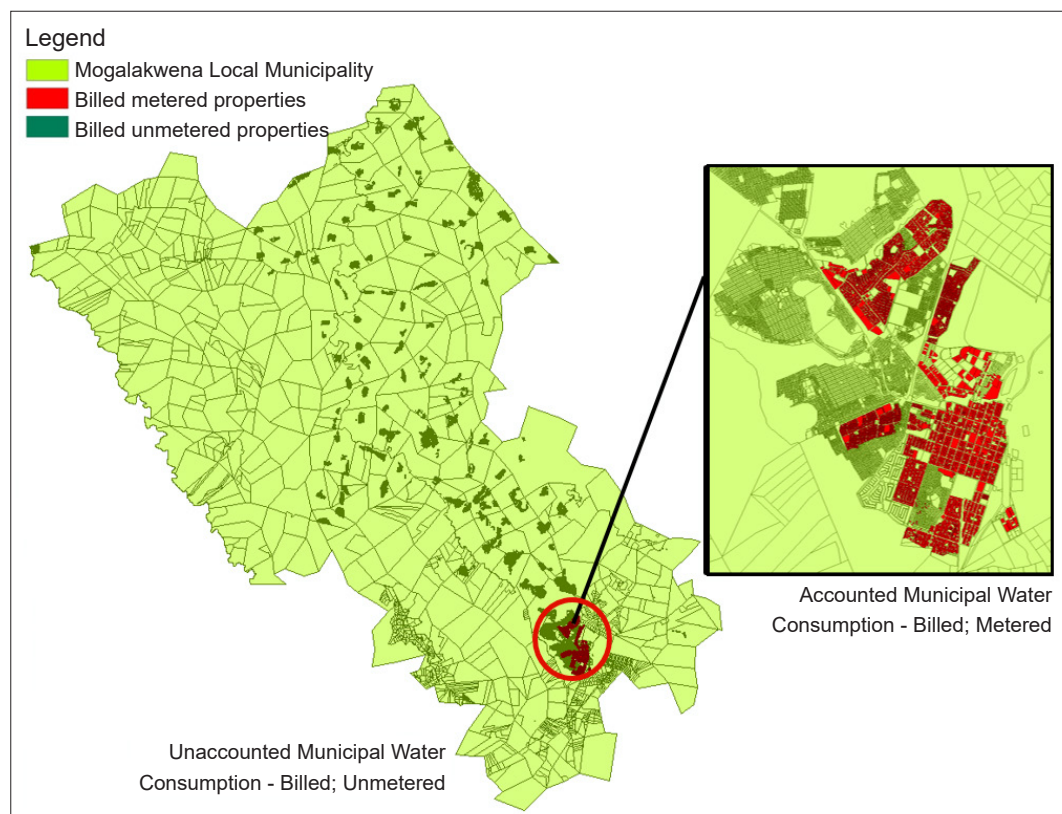

Figure 6: Extent of billed metered and unmetered water-consumption data availability in Mogalakwena Local Municipality

Source: Authors' own compilation

"identify, quantify and provide location requirements of engineering infrastructure and services provision for existing and future development needs for the next five years". Once again, referring back to Wong et al.'s (2013: 7) definition of a WSC where a "city can serve as a potential water supply catchment, providing a range of different water sources at a range of different scales, and for a range of different uses", spatial planners should rethink the design and use of buildings, infrastructure and spaces to include water-sensitive design practices such as decentralised waste-water treatment, rainwater, and storm-water harvesting techniques. These techniques are well documented (Rohilla, Matto, Jainer \&
Sharda, 2017: 33-52; Armitage et al., 2014: 49-75). As such, this article will not go into detail in explaining the techniques. Water-sensitive Spatial Development Frameworks could significantly reduce future water demand, and water quality can also be improved over time. In doing so, the overall sustainability of both the natural and the built environments will most likely improve, making the Municipality more resilient to climate change.

However, the above modelling exercises are limited to the availability of metered billing data. As such, two major land uses known for high water consumption, namely agriculture (responsible for nearly $60 \%$ of all water consumption nationally) and mining (responsible for nearly $3 \%$ of all water consumption nationally) is not included, due to the fact that these land uses acquire water directly from the Water Boards or from groundwater extracts, and therefore do not form part of the municipal billing system (DWA, 2013a: 9). Furthermore, the 178 villages (see section 6.1) located outside the urban fabric fall within the billed unmetered consumption (free basic services) (see section 3.2) category. Figure 5 illustrates the full extent of billed metered and unmetered water consumption. The full extent of water consumption by land use should be investigated when considering watersensitive spatial modelling.

Spatial modelling of growth and water demand thus provides opportunities to identify targeted areas and land uses to be developed, or conserved, either through water-demand reduction or implementations of green infrastructure and WSUD on a precinct level. By combining the future demand analysis with the spatial targeting intervention, a municipality will be able to determine where and how to best utilise resources.

The future demand for water as a resource, regarding quantity and quality, should form part of broader spatial planning and land-use management by translating water sensitivity into spatial planning practices. A point of departure is to identify the spatial impact of various land uses within a demarcated area, and use such data to make future growth and demand predictions, as illustrated in the Mogalakwena Local Municipality case study. This research argues that spatially targeted interventions, combined with WSUD approaches, can facilitate future sustainable development, but would require a shift in thinking from current silo-management to one where land, water, environment, and infrastructure are planned holistically. A transdisciplinary approach to spatial planning and water management is needed for the development and implementation of successful WSSs. 


\section{CONCLUSION: THE NEED FOR CHANGE AND INTERVENTION}

The "model" or figure presented in this article illustrates a means to identify which land uses demand higher quantities of water. This study has proven that, by combining various data sets within a modelling system (in this case Geographic Information System), spatial planners operating within the municipal environment can now quantify the water-resource impact of land-use decisions. Ultimately, the information can be used to inform spatial growth and resource-demand scenarios. As a Municipality, the information generated from this modelling exercise can be used to develop a business case for increasing water tariffs, re-evaluate the promised level of services, implement waterefficiency building regulations, and rethink the business-as-usual approach to settlement planning and design. Within the holistic context of a WSS, the starting point for many South African municipalities should be to understand and reduce the demand for water, before major interventions and infrastructure retrofitting are considered.

\section{ACKNOWLEDGEMENTS}

The financial assistance of the Water Research Commission (WRC) towards this research is hereby acknowledged. Opinions expressed and conclusions arrived at, are those of the author and are not necessarily to be attributed to the WRC.

\section{REFERENCES}

2030 WATER RESOURCE GROUP. 2009. Charting our water future: Economic frameworks to inform decision-making. s.I.: McKinsey \& Company.

ABEBE, F.K. 2011. Modelling informal settlement growth in Dar es Salaam. Unpublished Master's thesis, University of Twente, The Netherlands, Department of Urban and Regional Planning and Geo-Information Management.
ANGEL, S., PARENT, J., CIVCO, D.L. \& BLEI, A.M. 2010. Making room for a planet of cities. Cambridge, MA: Lincoln Institute of Land Policy.

ARMITAGE, N., FISHER-JEFFES, L., CARDEN, K., WINTER, K., NAIDOO, V., SPIEGEL, A., MAUCK, B. \& COULSEN, D. 2014. Water Sensitive Urban Design (WSUD) for South Africa: Framework and guidelines. Report to the Water Research Commission by Urban Water Management Research Unit Departments of Civil Engineering, Environmental and Geographical Science, Social Anthropology, and Political Studies, University of Cape Town, WRC Report no. TT 588/14.

BOSHOFF, L. 2014. Evidence-based spatial planning analysis for improved urban planning and management. Presented at the Annual World Bank Conference on Land and Poverty, 24-27 March 2014. Washington, DC: World Bank.

BROWN, R., KEATH, N. \& WONG, T. 2008. Transitioning to water-sensitive cities: Historical, current and future transition states. In: Proceedings of the $11^{\text {th }}$ International Conference on Urban Drainage, 31 August-5 September 2008, Edinburgh. Edinburgh, CD-ROM.

CILLIERS, J. \& CILLIERS, S. 2015. From green to gold: A South African example of valuing urban green spaces in some residential areas in Potchefstroom. Town and Regional Planning, 67, pp. 1-12.

\section{CSIR (COUNCIL FOR SCIENTIFIC} AND INDUSTRIAL RESEARCH). 2011. Research aids sustainable planning of cities 30 years ahead. Sciencescope, 2, pp. 18-19.

\section{DWA (DEPARTMENT OF WATER} AFFAIRS). 2013a. Proposed National Water Resource Strategy 2 (NWRS-2): Annexure B Understanding Water Resources. Pretoria: Department of Water Affairs.

DWA (DEPARTMENT OF WATER AFFAIRS). 2013b. National Water Resource Strategy, $2^{\text {nd }}$ edition (NWRS2). Pretoria: Department of Water Affairs.

DWS (DEPARTMENT OF WATER AND SANITATION). 2015. Strategic overview of the water service sector in South Africa 2015. Pretoria: Department of Water and Sanitation.
GAUTENG DEPARTMENT OF ECONOMIC DEVELOPMENT. 2011. The Gauteng Spatial Development Framework. Gauteng Provincial Government.

GOODLAND, R., ORLANDO, L. \& ANHANG, J. (Eds). 2001. Towards sustainable sanitation. Fargo, North Dakota: The International Association of Impact Assessment.

GRIMM, N.B., FAETH, S.H., GOLUBIEWSKI, N.E., REDMAN, C.L \& WU, J.G. 2008. Global change and the ecology of cities. Science, 319(5864), pp. 756-760. https://doi.org/10.1126/ science. 1150195

IWMI (INTERNATIONAL WATER MANAGEMENT INSTITUTE). 2006. Comprehensive assessment of water management in agriculture. Colombo, Sri Lanka: World Water Week in Stockholm.

MARSALEK, J., JIMÉNEZ-CISNEROS, B.E., MALMQUIST, A., KARAMOUZ, M., GOLDENFUM, J. \& CHOCAT, B. 2006. Urban water cycle processes and interactions. Paris: International Hydrological Programme (IHP) of the United Nations Educational, Scientific and Cultural Organization (UNESCO).

MOGALAKWENA LOCAL MUNICIPALITY. 2016. 2016/17 Integrated Development Plan Summary, Local Government, Mogalakwena Local Municipality.

NEL, J., DRIVER, A.L., STRYDOM, W.F., MAHERRY, A.M., PETERSEN, C., HILL, L., ROUX, D.J., NIENABER, S., VAN DEVENTER, H., SWARTZ, E.R. \& SMITH-ADAO, L.B. 2011. Atlas of freshwater ecosystems priority areas in South Africa: Map to support sustainable development of water resources. WRC Report no. TT 500/11. Pretoria: Water Research Commission.

O'MALLEY, P. 2016. Nelson Mandela Centre of Memory. [Online]. Available at: <https://www. nelsonmandela.org/omalley/index.php/ site/q/03lv01538/04lv01646/05Iv01758. htm> [Accessed: 3 March 2017].

OOSTHUIZEN, K. 2000. Demographic changes and sustainable land use in South Africa. Genus, 56(3/4), pp. 81-107.

ROHILLA, S.K., MATTO, M., JAINER, S. \& SHARDA, C. 2017. Watersensitive urban design and planning: $A$ practitioner's guide. New Delhi: Centre for Science and Environment. 
ROWLSTON, B. \& SCHREINER, B. 2011. Institutional arrangement for the protection of aquatic ecosystems. In: King, J. \& Pienaar, H. (Eds). Sustainable use of South Africa's inland waters. Republic of South Africa: Water Research Commission TT 49/11, pp. 49-79.

RSA (REPUBLIC OF SOUTH AFRICA). 2013. Spatial Planning and Land Use Management Act. Act no. 16 of 2013. Pretoria: Government Printer.

SACN (SOUTH AFRICA'S CITIES NETWORK). 2016. State of South African cities report 2016. Johannesburg: SACN.

SETO, K.C., FRAGKIAS, M., GÜNERALP, B. \& REILLY, M.K. 2011. A meta-analysis of global urban land expansion. PLoS ONE, 6(8), pp: e23777. https://doi.org/10.1371/journal. pone.0023777

SHOKO, M. \& SMIT, J. 2013. Use of agent-based modelling to investigate the dynamics of slum growth. South African Journal of Geomatics, 2(1), pp. 54-67.

STATISTICS SOUTH AFRICA. 2016. Community Survey 2016. Provinces at a glance Report 03-01-03. s.I.: Statistics South Africa.

SWPN (STRATEGIC WATER PARTNERS NETWORK SOUTH AFRICA) 2014. Creating shared value through innovative partnerships.

Pretoria: Department of Water and Sanitation.

UN (UNITED NATIONS). 2015. Transforming our world: The 2030 agenda for sustainable development $A /$ RES/70/1. s.I.: United Nations.

UN DESA (UNITED NATIONS DEPARTMENT OF ECONOMIC AND SOCIAL AFFAIRS). 2015. World population prospects: The 2015 revision, key findings and advance tables. Working Paper no. ESA/P/WP.241. New York: United Nations Department of Economic and Social Affairs.

UNITED NATIONS HABITAT. 2013.

Urban planning for city leaders. Nairobi: UN-Habitat.

UN-WATER. 2007. World water day: Coping with water scarcity. Challenges of the twenty-first century. s.I.:

UN-Water.

WONG, T. 2006. Water-sensitive urban design - the journey thus far. Australian Journal of Water Resources, 3(10), pp. 213-222.
WONG, T. \& BROWN, R. 2008.

Transitioning to water-sensitive cities: Ensuring resilience through a new hydro-social contract. In: Proceedings of the $11^{\text {th }}$ International Conference on Urban Drainage, 31 August-5 September 2008, Edinburgh. Edinburgh, pp: CD-ROM.

WONG, T.H., ALLEN, R., BROWN, R.R., DELETIĆ, A., GANGADHARAN, L., GERNJAK, W., JAKOB, C., JOHNSTONE, P., REEDER, M., TAPPER, N. \& VIETZ, G. 2013. Blueprint 2013 - storm-water management in a water-sensitive city. Melbourne, Australia: Cooperative Research Centre for Water-Sensitive Cities.

WINIWARTER, V., HAIDVOGL, G., HOHENSINNER, S., HAUER, F. \& BURKNER, M. 2016. The long-term evolution of urban waters and their nineteenth-century transformation in European cities. A comparative environmental history. Water History, 8(3), pp. 209-233. https://doi. org/10.1007/s12685-016-0172-z

WRAY, C., MUSANGO, J. \& DAMON, K. 2013. Modelling urban spatial change: A review of international and South African modelling initiatives. s.I.: Gauteng City-Region Observatory. 